\title{
State and Algorithms of Globalization
}

\author{
Valentin Yakovlevich Lyubashits ${ }^{1}$ \\ Andrey Yurievich Mordovtsev² \\ Alexey Yurievich Mamychev² \\ 'Southern Federal University \\ ${ }^{2}$ Vladivostok State University of Economics and Service \\ Email: mamychev@yandex.ru
}

\section{Doi:10.5901/mjss.2015.v6n3s6p277}

\begin{abstract}
The content of the article analyzes the processes (algorithms) globalization and its impact on the institution of the state. Various methodological approaches to the study of global processes and theoretical and practical models of transformation of state institutions. It is shown that modernization and globolokalnye trends significantly affect the meaning and the socio-cultural dynamics of the state as a political phenomenon, problematizing essence, the basic functions and tasks, the social role of public authorities in the political life of society. It is noted that the current process of globalization significantly increase risktaking functioning of local, national and regional living spaces, put in a tough relationship from the activities of the government. The paper concludes that the international political communication, based on national unity, sovereignty and national integrity, evolves in the direction of adapting (a constantly changing and perestrukturiruyuschihsya) cooperative arrangements, where state power is considered as one of the global actors involved in the political process on an equal basis with non-governmental civil institutions, transnational actors, the military-political blocs. At the same time, the authors argue that globalization is qualitatively enrich and complicate the role of the state, is justified, that this institution will not lose its dominant position in the international cooperation in the management of intra-national processes.
\end{abstract}

Keywords: Globalization, state, law, political processes, legal doctrines.

\section{Introduction}

The term "globalization" is derived from the French word «global» - universal. This term denotes an objective process of formation, functioning and development of a fundamentally new world system of relations between the countries and peoples on the basis of deepening the relationship and interdependence in all spheres of life of the world community (Kapto A., 2002, p. 106). Broadly speaking, under globalization on the one hand, it refers to escalating national and regional issues into global, and on the other - the formation of a common economic, social, and natural biological environment on a planetary scale. In the narrow sense of the word globalization is interpreted only in the socioeconomic aspect, as the transformation of national, societal and economic structures into a coherent and unified geosotsioekonomicheskuyu reality.

The processes of globalization, the unification of political development and standardization of social and economic organization of societies (Mordovtsev A.Yu., Mordovceva T.V., Mamychev A.Yu., 2015), legitimacy (or deligitimatsii) existing political regimes of the international community are responsible for a fundamentally different era in development of national states, other geopolitical matrix evaluation of existing problems and threats - on the one hand, options and prospects of interaction of civilization - on the other.

This era is considered by many analysts as the "parade of sovereignties soft" gradual desovereignization statelegal spaces scrapped "national-territorial instincts» (Rischard J.F., 2002) states, involving everyone (network) management of global political processes, "humanitarian intervention", standardization economic and political reality. Political clichés evaluation matrix transformations taking place was the expression of the famous political scientist Henry Kissinger that the modern world processes indicate "death" of the Westphalian system and the senselessness of the idea of state sovereignty, the idea of national-cultural development (G. Kissinger, 2002). If today to talk about sovereignty, it is only in the context of the combined (regional, international), global sovereignty, involving the integration of various states in a politically united (federal, network) unit, a qualitatively new form of "cosmopolitan organization» (Beck U., 2005). 


\section{Literature Review}

In today's political and legal science the process of globalization is seen in two ways (Giddens A., 1984). On the one hand, it is analyzed as a specific, objectively existing tendency par with processes such as regionalization, provincialism, localization, and others. It is proved that the process of globalization is not exclusively a product of our time, and is peculiar in one way or another and in various capacities, throughout the history of mankind (Proskurin S., 2002). This is due, primarily, the fact that one of the motives of human activity, as suggested by G.H. Shakhnazarov, was the need for communication, mutual understanding. This motivation is known to be manifested at different levels of human organization - from simple social systems - to the planetary community - "bringing people to clan, tribe, state, nation and the world community" (Shakhnazarov G.H., 2000, p. 186).

On the other hand, globalism is treated as a tendency to spread cultural and indifferent international standard, the global outlook (Giddens A., 1990), and a network of planetary consciousness, with "their dark sides" and generating "its own antithesis - the ideology and anti-globalization movement" (Neklessa A., 2002, p. 110). In this case, we are talking about the humanitarian, economic and political unification of the existing state-legal spaces in accordance with certain "standardized" the ideals and principles of the (Lyubashits V.Y., Mordovtsev A.Y., Mamychev A.Y., 2013).

\subsection{Realists}

Realists believe that in a globalized world the state continues to pursue its own interests. In international politics - says $\mathrm{N}$. Spykman - tolerated all forms of violence, including the destructive war. This means that the struggle for power is identical to the struggle for survival, and the main task of the state's domestic and foreign policy is strengthening the positions of power. Everything else is secondary (Spykman N.J., 1994, p. 18). According to George Donnelly, in a globalized world there is no world government that would guide the actions of states in the international arena. To survive in this arena, the government should pursue their own interests and more draws (Donnelly J., 2000, p. 12). Realists deny the impact of globalization to change the power of the state.

\subsection{Institutionalists}

The opposite position is taken by institutionalists. They predict the change of the national state institutions, transnational globalized world. K. Ohmae argues that globalization becomes a nation state "in a nostalgic feature" (Ohmae K., 1998, p. 12). According to Mr. Reynard, globalization challenges the sovereignty of the nation state (Reinicke W.H., 1997, p. 129). Overgrown international organizations and regimes, internalization of international norms of local civil society lead to the erosion of national sovereignty.

In studies institutionalists, devoted to the study of this process highlights one of its most important consequences to change the functions of the state system (State ..., 2003). If the first public institutions to decide independently upon the basic parameters of the national domestic and foreign policy in the economic and social spheres carried undivided border controls over the movement of people and goods through its territory, today the concept of national sovereignty is eroded. The most powerful economic and military aspects of the state are having a greater impact on both the domestic and the foreign policy situation in the less powerful countries. Another important consequence of the globalization of the modern world is the emergence of supranational institutions, giving signs of interstate relations of the federal structure. This is most clearly seen in the European Union.

\subsection{Structural and functional studies}

Overcoming extreme positions of realists and institutionalists is systemic-functional approach (Merton R.K., 1957), the landmark on the study of the processes of adaptation of the state for the challenges of the globalized world. During this adaptation changes the nature of the government and the adjustment of government functions (Mamychev A.Yu., Kiyashko E.Yu., Timofeeva A.A., 2015).

Thus, the development of political systems in the current international situation indicates an increase in the functional role of the government. In contrast to the theory of "weakening of sovereign quality," states observe the process of increasing the role of government institutions, not only in the management of subnational space, but also in the international arena - in the settlement of various conflicts. Therefore, in the framework of structural-functional approach it argues that today should not speak about the "withering away" of the state institution, and its adaptation to changing operating conditions: "The State and bodies still have to go through the difficult process of adapting to the 
changing conditions of a globalizing world, but now it is clear that it affects not only the fate of the state and to overcome it, even if modified, but just as important, as before, the historical mission "(Globalization ... 2006, p. 105).

\section{Methods and Materials}

In the current political and legal studies, there is a whole diversity of methodological positions and theoretical and practical approaches to understanding the processes of globalization and political simulation algorithms development institute of the state in a globalizing world. If you organize all these positions and approaches, we can distinguish three main areas that are subject to the stated problems. The first methodological direction is to interpret the processes of globalization from the perspective of the relationship and interdependence of national systems of public authorities, in the implementation of its internal and external functional activities, in the context of steadily increasing international political and socio-economic interdependence, transnational flows, convergence of political and socio-cultural identities linkages (Held D., McGrew A., Goldblatt D., Perration J., 1999).

The second methodological direction focuses on the convergence and unification of political forms and means of communication (Geddes A., Favell A., 1999). Here globalization political and legal thought process not in terms of the increasing interdependence of national public spaces - in the first case, and from the point of view of globalization within these spaces, their openness and "readiness" to the global transformation of political institutions and practices.

The third methodological direction considering globalization as a qualitative transformation of political and legal forms of organization, in the context of which the national government ceases to "create a common procedure for the relationship" and stimulates new cosmopolitan principles of human life. These processes lead to the fact that the "world domestic policy space power is conceptually and politically mastered outside the old categories of national and international" and open "perspective cosmopolitan policy updates and the state» (Beck U., 2005, p. 15).

In addition, we note that the current study is based on comparative policy and comparative legal methods, by comparing trends and development trends of political and legal processes in various state-legal spaces, as well as the historical and political, which allows to describe the transformation of the government in the course of development global and national political process. For the analysis of trends and prospects of the political phenomenon of state power in the modern globalized world use methods of political modeling and semantic analysis of the current political and ideological discourses.

The empirical base of the study was informative, sociological and factual sources containing information about the specifics of the transformation of modern political process and the government, changes its role, importance and functions of basic contradictions, conflicts and risks. The paper also uses a variety of analytical materials reflecting the system functions and the structure of state power at the turn of the XX - XXI centuries., The development of the main activities of the institutions of power.

\section{Results and Discussion}

Referring to changes in the power and functions of the state in the global economy. These changes roots date back to the height of the Cold War that split the world into two poles. During this period, the national states of Western Europe began the processes of economic, political and military union, which, according to P. Van Ham, two main factors have contributed (Ham van, P., 1994). Firstly, it is the threat posed by the countries - members of the Warsaw Pact, which has forced European nations to put aside their historic quarrels and unite against the common enemy. Secondly, European integration has spurred the postwar dominance of the United States. In the face of the Soviet threat, the Americans have invested heavily in strengthening the defense of Western Europe, which allowed the latter to divert significant resources on the economic development. Consequently, it is external factors contributed to the unthinkable in the recent past of interstate cooperation in the post-war Europe.

The most important feature of the current post-war Europe, the institutional structure is the relative stabilization of the state and territorial boundaries. Western European states did not seek to increase their power at the expense of territorial expansion that interrupted the previous course of history in this part of the world. The emergence of new regimes and international organizations to reduce the need for nation states to resort to unilateral means to ensure its own security and defend their interests. They increasingly began to assess their economic well-being, rather than geopolitical aspects. If over a long period of time the state held mainly on territorial conquests, in this period, they begin to focus on control of the distribution of the world's resources as the primary means of ensuring their well-being. Products gradually acquired greater mobility than capital and labor, resulting in a trade States (Rosecrance R., 1986, p.)

Commercial State has a number of special characteristics. Firstly, it does not consider the military as an attribute of competition authorities. The trappings of power, it believes international trade. Until the mid-twentieth century. cost- 
effective was the capture of foreign territory by force, rather than the creation of sophisticated economic and trade institutions, profitable from the commercial exchange of goods with neighboring territories. Today, the price of power is greater than the welfare of the economic benefits that it brings. The spread of modern weapons, such as nuclear, biological and chemical, they possess destructive potential cause strong resistance from the public and provoke unnecessary conflicts in society. In addition, the state is pursuing trade and economic development based on the principles of the free market and not on the basis of the mercantilist model, focused only on obtaining profits. Therefore, it seeks to adapt the structure of local markets and to the norms of the international market.

The development of the European market has resulted in a major change of power of the state and the redefinition of its role in economic processes. The function of the state was the organization and protection of the self-regulating market (Ruggie JG, 1983, p. 202). When the values of liberal democracy advocate consumer welfare and autonomy of the market, and the state plays a minor role. The modern state tend to bear a permanent responsibility to ensure people's goods and the correction of errors of the market to promote economic growth and stability. Therefore, the trading states were formed various political and economic interests in comparison with the previous nation-state. Focusing on trade and not on the power of expansion, state trade most of its resources allocated to the development and manufacture of new products and the conquest of new positions in the international market. Those countries that are fully integrated into the global market, have a very good economic growth even in the face of lack of natural resources. Examples include Singapore, and Taiwan. At the same time, the country focused on the neglect of the globalization process, no matter what natural resources they possess, are on the side of the world economic space, as exemplified by the position of the Soviet Union (Putnam R., 1993, p. 77). Shopping states are better able to cooperate with each other and to establish institutions and regimes that restrict international anarchy. They also acquire an interest in developing and maintaining economic prosperity in the partner countries, since beginning to make direct investments in their economies. These investments relate to industrial infrastructure, so they are not highly liquid within the local market. That mutual investing develops cooperative trend at the international level. And these cooperative trend is not just in trying to harmonize the economic policies of each other, but also in the desire to bear short-term losses while trading partners to adjust to the new policy.

The emergence of such tendencies caused by the cooperative action of three factors. First, state trade based on the open international trading system, which eliminates barriers such as tariffs, quotas and price support, must include free and open trade and ensures free movement of capital. In such a system the state are able to invest freely with each other. Second, trading States shall ensure its own security through collective efforts and not through isolation. States of Western Europe in the last forty years can significantly save their defense spending, as some countries do not carry their own, but as part of a pan-European security system. Third, trade recognize that in an interdependent world, they can not take a position of ignoring international organizations and regimes without serious economic and political losses for themselves. In other words, full independence and freedom of action of individual nations - it is quite unrealistic expectations in modern international politics.

In Western Europe, the result of cooperative tendencies between trading nations is to strengthen trade ties. After signing the Treaty of Rome in 1957, 37\% of exports of the twelve countries of the European Union accounted for a common internal European market. In 1970 this share had increased to 53\%, and by 1991 these exports amounted to 61\% of the turnover of the EU (Cable V., 1994, p. 90). Moreover, since 1980, when GDP growth of 12 EU countries was within 2.1\% per year and an increase in external trade outside the EU was approximately $1.1 \%$ per year, the growth of trade within the EU was within $42 \%$ per year. Overriding result of this socioeconomic process was a complete rejection of war as a means of resolving political issues, however, this was accompanied by the growth of limited autonomy of the national state.

Trade limited state prevailing in the evolution of "permanent norms" of international relations. Constant rate called such rules the relationship, which can disturb unless specifically justified. Examples of such standards can serve as a rule of "the contract must always be made" and "debts always have to give." Such rules voluntarily accepted the participants of the relationship because they are perceived as the best means of achieving the objectives. If states believe that they can achieve certain goals by yourself, paying a reasonable price, they avoid involvement in such a system of relations. However, it is clear that the benefits of adoption of state autonomy restrictions imposed by the regime of trade relations should be much larger. Otherwise it would have such a system is not widespread in the modern world.

The integration of the global economy is uneven and leads to a degree of inequality of economic power. Vladislav Inozemtsev notes the trend strengthening cooperative ties closure economically powerful nations. According to statistics on the trends of modern international trade, investment and movement of labor flows (V. Inozemtsev, 2000, p. 31).

Throughout the twentieth century, the growth of trade turnover exceeded the growth of GDP of most industrialized countries. If the total GNP of all countries of the world increased from 1950 to 1992 from 3.8 to 18.9 bln. dollars, the volume of trade turnover increased from 0.3 to 3.5 trillion. dollars. In the late ' $80 \mathrm{~s}$ - early' $90 \mathrm{~s}$ the growth of world trade was characterized by rates ranging from 5.3 to $7 \%$ year on year. Meanwhile, the structure of these trade flows has 
changed significantly. In 1953, the industrialized countries were sent to the country reached the same level of development, 38\% of the total volume of total exports, in 1963 this figure was 49\%, in 1973 - 54\%, in 1987 - 54.6\% and in $1990-76 \%$. In the second half of the '90s post-industrial powers imported from developing and industrialized countries for goods and services in an amount not exceeding 1.2\% of their combined GNP. In 1996, the ratio of exports to GDP in the United States was three times less than in England 150 years ago, in the mid 40-ies of the XIX century. In Europe, formal indicators were higher, but this is because the flow of goods within the $\mathrm{EU}$, which accounted for $74 \%$ of exportimport operations of the European countries considered as international. The picture has changed dramatically with the completion of the formation of the European Union. The value of trade flows between the EU and developing countries (excluding China) today is less than the volume of trade with Switzerland (Inozemtsev V., 2000, p. 30).

Even more indicative of the dynamics of international investment flows, disclosed by the example of the United States. On the one hand, despite the increase in investment in the US economy is 30 times during the period from 1970 to 1990, the company's 7 countries - Britain, Japan, Canada, France, Germany, Switzerland and the Netherlands provide a total of $85 \%$ of all investments in the US and the recipients for more than $60 \%$ of all American investments abroad. If in 1970 in Europe is not directed more than a third of all American investments today - more than 50\% (in the newly industrialized countries of Asia - not more than 8\%, and in Mexico - about 3\%). At the same time the developed countries to invest in the most advanced sectors of the economy of each other. At the beginning of the $90 \mathrm{~s} 63 \%$ of US investment in the European countries were sent to the service sector, and 31 - in industrial production; Europeans to invest in American industry (49\%), as well as in banking and finance (25\%). In contrast, investors from Japan and the newly industrialized countries prefer to only speculative investments or limited purchase of trading companies (41\%) and real estate (30\%). The share of Japanese investment in the industrial production does not exceed $18 \%$ for the US and $16 \%$ - to the EU. The degree of monopolization of financial transactions within the framework of the developed world is even more obvious.

There are contradictory effects of globalization on the labor market. Reducing immigration to developed countries has become a reality, since the mid-70s. Today in the EU, only $2 \%$ of the workforce find application outside national borders. Simultaneously, the pressure on the post-industrial country by immigrants from "third" world. If in the 50 s $68 \%$ of legal immigrants arriving in the United States came from Europe or Canada, and belonged to the middle class, then in the 80s more than $83 \%$ were Asian, and Hispanic. They usually did not have enough education. In European countries, like the United States, immigrants swell the lower classes of society and create tough competition for local workers. Today, the youth negative attitude towards immigrants is shared by $27.3 \%$ to $39.6 \%$ of the French and Germans, $41 \%$ of Belgians. In the United States alone over the past three years, the administration of a number of districts of the six largest states - California, Florida, New York, Arizona, Texas and New Jersey - initiated formal legal proceedings against the federal government (the amount varied from 50 million. To $\$ 33$ billion. Dollars ), requiring them to compensate for the financial losses caused by lax national immigration laws. According V.Inozemtseva, the next decade will be for the US and the EU over a period of stringent restrictions on the use of foreign labor.

\section{Conclusion}

Distribution and strengthening international organizations and regimes proved a challenge to the traditional concept of state sovereignty. Realists argue that the nation-state remains a major participant in the global system of relations, and international institutions have expressed their will. Institutionalists argue that international organizations and regimes limit the independence of the modern state in the exercise of their functions. Overcoming extreme voluntaristic approach realists and procedural institutionalist approach is a broader systemic-functional analysis. Modern State internalizes international norms and rules, limiting the traditional sovereignty and simultaneously acquires new functions of a Member State of the international community, which increases the power of the state in solving internal and external problems.

In the post-Cold period of global economic institutions, international organizations and regimes have limited independent activity of the state. State participation in the global economy leads to a type of state of trade, which measures its power share of world economic resources, rather than the size of the territory and military power. Trade state directs most of its resources on the development and manufacture of new products and the conquest of new positions in the international market. Shop the state is interested in maintaining economic prosperity in the countries partners, as carries out direct investment in their economies. Interdependence of trade accompanied by the emergence of the state of inequality in the degree of economic power. States developing on the basis of a post-industrial, form a closed system, while the industrial and pre-industrial countries are in a position depending on the system. This is evidenced by the closure of the trade and investment flows within the post-industrial system, its increasing resistance to the periphery of the sweeping economic crisis and tightening of immigration policy. 
Now there is the development of legal structures and political forms that adequately describe the current functioning of state institutions and their development prospects in the cosmopolitan world of criteria and characteristics tipologiziruyuschih "sovereign quality" of the state, make their reality (or nominee), factuality (virtual) and etc. For example, the concept of "the power of the state" in the present conditions explicitly or implicitly expresses the potential and the ability of state power independently and determine the goals and objectives of the national political and legal space, "dialogical" to participate in the international legal and policy on equal act As one of the "architects" of the international security system, the leading subject of global political and economic system.

In the modern political practice emphasizes the growing importance of regulating the activities and programs of the government, aimed at overcoming the crisis, contradictions, conflicts and ensuring social order, stability and sustainable development of the social system. However, the extent of such power-management intervention in social processes and its impact on the regulation of social activity depends on national traditions prevailing public law practice of interaction between society and the state, as well as preferences, interests and needs of the population. Therefore, post-classical concept of evolution of government institutions, leveling its sovereign quality, justifying the erosion of traditional roles and the value of this institution, the transformation of its competencies should be interpreted not only as a challenge to selfreliance, independence and integrity of the national state, but as a threat to the continued existence of state-organized forms life. We believe that the guidelines further state-building and the strengthening of political systems associated with the development of the concept of stability and sustainability of public law institutions of power, forms and models of cooperation in the personality - society - state, ensures the continuity of the reproduction of national and cultural integrity and identity standardize and unify the world as well as independence in decision-making and management of national implementation of legal policy.

The global transformation of the state, law, civil society and human rights doctrine, of course, makes a call to the national state power, its sovereignty and independence of its functions, priorities and so on. Of course, globalization is qualitatively enrich and complicate the role of the state, but it is unlikely the institution will lose its dominant position in the international cooperation in the management of intra-national processes.

\section{References}

Globalization and state unity of Russia (2006) / B.S. Ebzeev, R.A. Aybazov \& S.L. Krasnoryadtsev, holes. Ed. BS Ebzeev. M.

State and society in the context of globalization: a view from the left (2003) / Ed. A.A. Galkina. M.

Inozemtsev, V. (2000) Globalization: Illusions and Reality // Free Thought - XXI century. Number 1.

Kissinger, G. (2002), Does America Need a Foreign Policy. M.

Kapto, A.S. (2002) Encyclopedia of the world. M.

Lyubashits, V.J., Mordovtsev A.Y. \& A.Y. Mamychev (2013) The state power: the paradigm, the methodology, typology. M. Neklessa, A.I. (2002) Globalization and the new geo-economic world order // Philosophy economy. No.1.

Proskurin, S. (2002) Globalization as a factor in the polarization of the modern world. M.

Shakhnazarov, G.H. (2000) Globalization and global studies - the phenomenon and the theory // Pro et contra. Number 4.

Beck Ulrich (2005) Power in the Global Age. Cambridge: Polity Press.

Cable, V. (1994) Key Trends in the European Economy and Future Scenarios // In: Miall, ed., Redefining Europe, n. 24.

Donnelly, J. (2000) Realism and International relations/ Cambridge.

Ham Van, P. Can Institutions Hold Europe Together? (1994) In: Miall H., ed., Redefining Europe: New Patterns of Conflict and Cooperation. London, 1994.

Held, D., McGrew A., Goldblatt D. \& Perration J. (1999) Global Transformation. Cambridge: Polity Press.

Geddes, A., Favell A. (1999) The Politics of Belonging: Migrants and Minorities in Contemporary Europe. Aldershot: Ashgate.

Giddens, A. (1984) Constitution of Society: Outline of the Theory of Structuration. Berkeley; Los Angeles: University Press.

Giddens, A. (1990) The Consequences of Modernity. Stanford: Stanford University Press.

Mamychev, A.Yu., Kiyashko E.Yu. \& Timofeeva A.A. (2015) Conservative political transformation projects of Russian power: the main discourses of modernity // Mediterranean Journal of Social Sciences. Vol. 6, № 3, May. Supplement 2. pp. 389-396.

Merton, R.K. (1957) Social Theory and Social Structure / Robert K. Merton. Enl. Ed. New York: Free press

Mordovtsev, A. Yu., Mordovceva T.V. \& Mamychev A.Yu. (2015) Convergence of law: the variety of discourses // Mediterranean Journal of Social Sciences. Vol. 6, № 3, May 2015. pp. $262-268$.

Ohmae, K. (1998) The End of the nation State. L.

Putnam, R. (1993) Two-Level Games: The Impact of Domestic Politics on Transatlantic Bargaining // In Haftendorm H. And Tuschhoff C. eds., America and Europe in an Era of Change. Boulder.

Reinicke, W.H. (1997) Global public Policy // «Foreign affairs»:Wash., V.76, № 6.

Rosecrance, R. (1986) The Rise of the Trading State: Commerce and Conquest in the Modern World. N.Y.

Ruggie, J.G. (1983) International Regimes, Transactions and Change: Embedded Liberalism in the Postwar Economic Order // Krasner S., ed. International Regimes. Ithaca.

Spykman, N.J. (1994) American Strategy in Worldpolitik: The United States and the Balance of Power. N.Y.

Rischard, J.F. (2002) High Noon: Twenty Global Problems, Twenty Years to Solve Them. BASIC BOOKS, New York. 